\title{
Reaktif Azot Türlerinin (RNS) Üretimi, Fonksiyonu ve Stres Koşullarındaki Durumu
}

\author{
İlkay Yavaş $^{1 *}$, Volkan Mehmet Çınar ${ }^{2}$, Aydın Ünay $^{3}$ \\ 1 Aydın Adnan Menderes Üniversitesi Koçarı MYO, Bitkisel ve Hayvansal Üretim Bölümü, Aydın, (ORCID: 0000-0002-6863-9631) \\ ${ }^{2}$ Aydın Adnan Menderes Üniversitesi Fen Bilimleri Enstitüsü, Tarla Bitkileri ABD, Aydın, (ORCID: 0000-0001-5822-5649) \\ ${ }^{3}$ Aydın Adnan Menderes Üniversitesi Ziraat Fakültesi, Tarla Bitkileri Bölümü, Aydın, (ORCID: 0000-0002-7278-4428)
}

(İlk Geliş Tarihi 3 Şubat 2020 ve Kabul Tarihi 5 Mart 2020)

(DOI: $10.31590 /$ ejosat.683895)

ATIF/REFERENCE: Yavaş, İ., Çınar V.M., \& Ünay, A. (2020). Reaktif Azot Türlerinin (RNS) Üretimi, Fonksiyonu ve Stres Koşullarındaki Durumu. Avrupa Bilim ve Teknoloji Dergisi, (18), 435-444.

$\ddot{O} \mathbf{z}$

Bitkilerde Reaktif Azot Türlerinin (RNS) biyotik ve abiyotik stres koşullarında sinyal molekülü olarak rol oynadığı, buna karşın varlığının oksidatif hasara yol açtığı bilinmektedir. Kloroplast, mitokondri, peroksizom, endoplazmik retikulum ve plazma memranları RNS'lerin ortaya çıtı̆̆ı hücre organelleridir. Sitoplazmada nitrat redükdaz enziminin nitrik oksit (NO) üretiminden sorumlu en önemli enzim olduğu ortaya konulmuştur. NO birçok enzim, substrat ve hormonlar ile etkileşime girerek fizyolojik olayların düzenlenmesinde rol oynamaktadır. Bitki metabolizmasında aşırı konsantrasyonlarda üretildiğinde ise reaktif oksijen türlerinde olduğu gibi birçok enzim tarafından etkisiz forma dönüştürülmektedir. Bu yönden RNS'lerin üretimi, fizyolojik etkileri ve etkisizleştirilmeleri birçok fizyolojik olayı tanımlamada önemlidir.

Anahtar Kelimeler: Abiotik stres, dormansi, nitrik oksit, reaktif azot türleri, stoma

\section{Production and Function of Reactive Nitrogen Species (RNS) and Status in Stress Conditions}

\begin{abstract}
It is known that Reactive Nitrogen Species (RNS) play a role as a signaling molecule under biotic and abiotic stress conditions in plants, but its presence causes oxidative damage. Chloroplasts, mitochondria, peroxisomes, endoplasmic reticulum and plasma membranes are cell organelles in which RNS occur. It has been shown that nitrate reductase enzyme is the most important enzyme responsible for nitric oxide (NO) production in cytoplasm. NO interacts with many enzymes, substrates and hormones and plays a role in the regulation of physiological events. In this respect, production, physiological effects and inactivation of RNS are important in defining many physiological events.
\end{abstract}

Keywords: Abiotic stress, dormancy, nitric oxide, reactive nitrogen species, stomata

\footnotetext{
* Sorumlu Yazar: Aydın Adnan Menderes Üniversitesi Koçarlı MYO, Bitkisel ve Hayvansal Üretim Bölümü, Aydın, Turkey, ORCID: 0000-0002-6863-9631, iyavas@ adu.edu.tr, Tel: +90 (256) 77273 48, Fax: +90 (256) 7727460
} 


\section{Giriş}

Bitkilerdeki Reaktif Azot Türleri (RNS), 1960'lı yılların başlarında Fewson ve Nicholas (1960) tarafından tanımlanmıştır. Nitrik oksitin (NO) yaprak yaşlanmasına (Leshem ve Haramaty, 1996) ve bitki bağışıklık sistemine etkisi (Noritake vd., 1996) incelenmiştir. Delledonne vd. (1998) ve Durner vd. (1998), bitkilerde nitrik oksitin, bitki savunmasında bakteriyel enfeksiyona karşı bir sinyal molekülü olarak rol oynadığını belirtmişlerdir. Bitki patogenezisindeki NO'nun bu yeni fonksiyonu, bitkilerde NO'nun fizyoloj ik rolü üzerine araştırmalarda çok önemli bir dönüm noktası olmuştur. RNS için sinyal molekülü ve "nitrosatif stres" tanımlamaları yapılmıştır (Beligni vd., 2002; De Michele vd., 2009; Hebelstrup ve Møller, 2015; Türkan, 2018).

Reaktif azot türleri (RNS), stres koşullarında ve normal yetiştirme şartlarında bitki büyüme ve gelişiminde çeşitli biyolojik süreçlerin düzenlenmesinde rol oynaması nedeniyle önem kazanmaktadır. Reaktif oksijen türleri (ROS) gibi reaktif azot türleri (RNS) de stres koşullarında serbest radikal ve radikal olmayan moleküller üretmektedirler. RNS, çeşitli stres tolerans mekanizmalarında önemli bir sinyal bileşeni olarak görev yapan nitrik oksitten $(\cdot \mathrm{NO})$ elde edilmekte ve bir kısmı da azot döngüsünde yer almaktadır. Bitkilerde esas olarak RNS, $\cdot \mathrm{NO}$ ve azot dioksit $\left(\cdot \mathrm{NO}_{2}\right)$ gibi serbest radikalleri ve radikal olmayan S-nitrosotiyoller, peroksinitrit $\left(\mathrm{ONOO}^{-}\right)$, nitroksil anyon $\left(\mathrm{NO}^{-}\right)$, nitrat $\left(\mathrm{NO}_{3}\right)$, nitrosonyum katyonu $\left(\mathrm{NO}^{+}\right)$, dinitrojen trioksit $\left(\mathrm{N}_{2} \mathrm{O}_{3}\right)$, dinitrojen tetroksit $\left(\mathrm{N}_{2} \mathrm{O}_{4}\right)$, nitril klorür $\left(\mathrm{NO}_{2} \mathrm{Cl}\right)$ ve nitrik oksiti $\left(\mathrm{HNO}_{2}\right)$ içermektedir. Nitrik oksit, azot dioksit, nitrik asit, peroksinitrit ve dinitrojen tetroksit gibi RNS'ler, tohum dormansisi ve çimlenmesi, bitki büyüme ve gelişmesi, stoma hareketleri, üreme ve polen tüpü gelişimi, yaşlanma ve yaprak dökülmesi, baklagil-Rhizobium simbiyotik ilişkisi gibi çeşitli fizyolojik süreçlerde rol oynamaktadır. Ayrıca kuraklık, tuzluluk, soğuk, sıcaklık ve ağır metaller gibi çeşitli abiyotik stres koşullarında RNS bir sinyal molekülü olarak görev yapmaktadır. Bunlara bağlı olarak RNS'nin fizyolojik olayların düzenlenmesi ve nitrosatif stres de dahil olmak üzere bitki hücrelerinde iki farklı rol üstlendiği bilinmektedir (Adams vd., 2015; Malerba ve Cerena, 2015).

Özellikle tuz stresi koşullarında çeltik, mısır, buğday, domates ve kültür bitkilerinde, Arabidopsis ve ve halofitlerde RNS'in rolü üzerine çok sayıda çalışma yer almaktadır. $\cdot \mathrm{NO}$, melatonin ve $\mathrm{H}_{2} \mathrm{O}_{2}$ donör molekülleri uygulamasının bazı bitki türlerinde tuz stresinin etkilerini çeşitli mekanizmalar ile önleyebildiği belirtilmiştir. Reaktif azot türleri arasında, en fazla çalışma NO üzerinedir. $\mathrm{Bu}$ molekül tuza aşırı duyarlı, $\mathrm{Ca}^{+2}$ ve protein kinaza bağımlı ve tuz stresi altında G-protein aracılığı ile sinyal iletimi olmak üzere çok sayıda olayı düzenleyen bir moleküldür. NO'in hormonlar ve reaktif oksijen türleri ile olan karşılıklı etkileşimi absisik asit (ABA) kaynaklı stomaların kapanmasında rol oynamaktadır. Ayrıca mitoz bölünme ile aktifleşen protein kinaz (MAPK) ve siklik GMP (cGMP) aktivitelerini tetiklemektedir. Absisik asit, oksin, giberellin ve etilen gibi hormonlar tuz stresine tepkinin düzenlenmesi için RNS ile sinerjik veya antagonistik olarak etkileşime girmektedir (Lindermayr ve Jörg Durner, 2015; Saddhe vd., 2019).

$\mathrm{Bu}$ derlemede, bitkilerde reaktif azot türlerinin üretimi, hücre içi fonksiyonları ve stres koşullarındaki etkileşiminin fizyolojik temelleri üzerinde durulmuştur.

\section{Bitki Solunumunda Elektron Taşıma Sistemi (ETS) ve Kompleksler}

Hücresel bitki solunumunda, organik bileşikler oksitlenerek ATP formunda kullanılabilir kimyasal enerjiye dönüşmektedir. Bu olayın merkezinde mitokondride yer alan elektron taşıma sistemi (ETS) bulunmaktadır. Bu, NADH dehidrogenaz (kompleks I), süksinat dehidrogenaz (kompleks II), sitokrom c redüktaz (kompleks III) ve sitokrom c oksidaz (kompleks IV) gibi 4 oksidoredüktaz kompleksinden oluşmaktadır (Şekil 1). Ayrıca bu sistemde sitokrom c ve lipid ubiquinon gibi 2 hareketli elektron taşıyıcısı yer almaktadır. Genel olarak, elektronlar NADH veya FADH2 koenzimlerinden suya indirgenmiş moleküler oksijene aktarılmaktadır. Dört oksidoredüktaz kompleksinden üçü (kompleks I, III ve IV) elektron transfer reaksiyonlarını iç mitokondriyal zar boyunca proton translokasyonu ile birleştirmektedir. Sonuç olarak, ADP'nin fosforilasyonu için ATP sentaz kompleksi (kompleks V) tarafindan kullanılabilecek bir proton gradyanı oluşturulmaktadır. Klasik olarak açıklanan formunda, hücresel solunum, doğrusal bir ETS'ye (NADH'den I, III ve IV kompleksleri yoluyla moleküler oksijene kadar) dayanmaktadır. Bununla birlikte, elektronlar ETS' ye birkaç alternatif noktada girebilmektedir. Bu özellikle çok dallı olan bitki ETS sistemi için geçerli olmaktadır (Schertl ve Braun, 2014). 


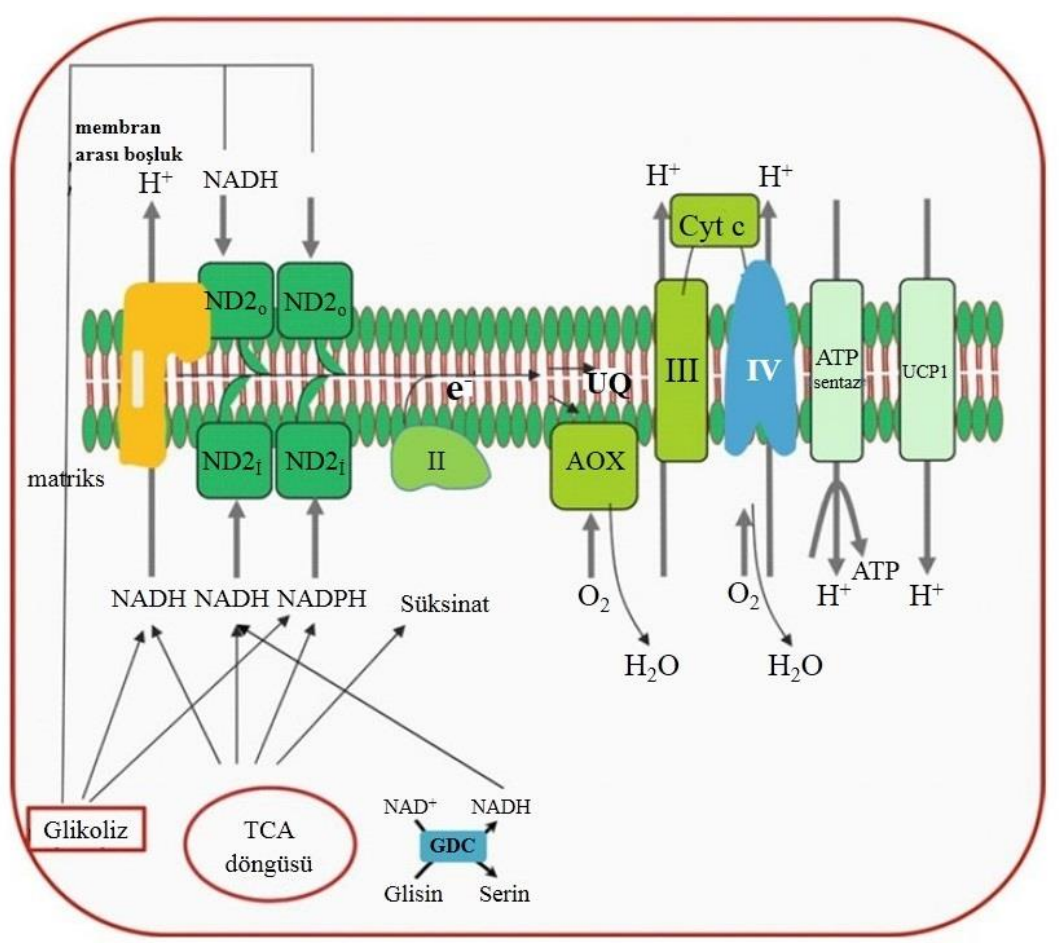

Şekil 1. Bitki mitokondriyal elektron taşıma zinciri ve çeşitli substrat kaynaklarının şeması. I, II, III, IV ve Vkompleksler, UCP ayrıştırıcı protein, AOX alternatif oksidaz, ND2 NAD (P) H dehidrogenazlar, GDC glisin dekarboksilaz kompleksi, UQ ubiquinon havuzu (Gupta ve Rolletschek (2013)’den değiştirilerek)

\section{Bitkilerde RNS Üretimi ve Fonksiyonları}

Reaktif azot türleri (RNS), nitrik asit $(\mathrm{NO})$ ve nitrik dioksit $\left(\mathrm{NO}_{2}\right)$ gibi radikalleri ve ayrıca nitröz asit $\left(\mathrm{HNO}_{2}\right)$ ve dinitrojen tetroksit $\left(\mathrm{N}_{2} \mathrm{O}_{4}\right)$ gibi radikal olmayanları içermektedir (Tablo 1).

Tablo 1. Reaktif azot türleri (RNS)

\begin{tabular}{ll}
\hline Serbest radikaller & Radikal olmayanlar \\
\hline Nitrik oksit NO. & Nitröz asit, HNO2 \\
Nitrik dioksit, NO2. & Nitrosonyum katyonu, NO+ \\
Nitrat radikali, NO3. & Nitroksil anyonu, NO- \\
& Peroksinitrit, ONOO- \\
& Dinitrojen tetroksit, N2O4 \\
& Dinitrojen trioksit, N2O3
\end{tabular}

Mitokondrideki NO üretiminin elektron taşıma zinciri, kompleks I,II, III ev IV, alternatif NAD(P)H dehidrogenazlar, alternatif oksidaz ve sitokrom c gibi yolakların tümünde ortaya çıkabileceği bildirilmiştir (Gupta vd., 2018). Nitrik oksit, L-arginin'den üretilmektedir ve kalmodulin bağımlı bir mekanizma sinyali ile kalsiyum tarafından sıkı bir şekilde düzenlenmektedir (Adams vd., 2015) (Şekil 2). RNS, mitokondride solunum, kloroplastlarda fotosentez, sitozolde oksidasyon-redüksiyon reaksiyonları ve peroksizomlarda hücresel fotorespirasyon gibi olaylarda, bitkilerde farklı yerlerde çeşitli kimyasal reaksiyonlar sonucu üretilmektedir ve RNS'nin, çeşitli sinyal yollarında önemli rolleri bulunmaktadır. Proteinler (örneğin, glutaredoksinler, tioredoksinler, sülfiredoksin, peroksiroksinler vs.) tiollerin düzenlenmesine katkıda bulunmakta ya da azaltmaktadır. 


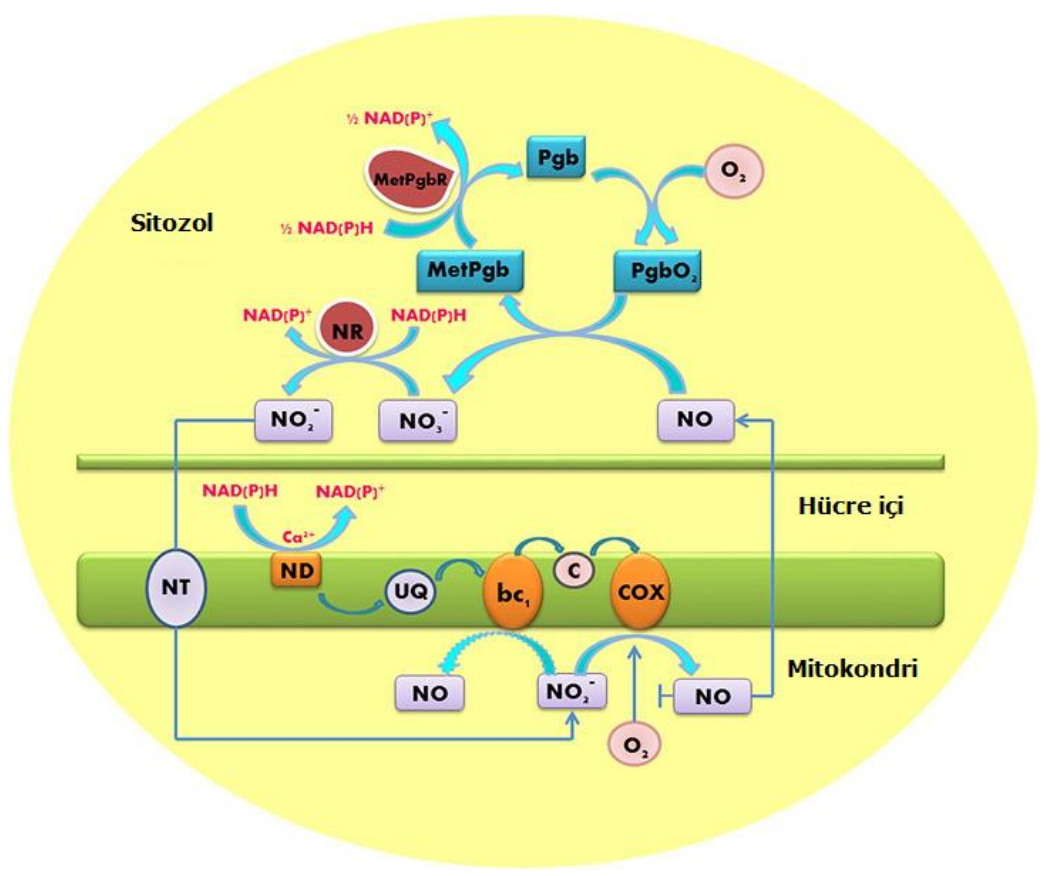

Şekil 2. Fitoglobin / NO döngüsünün anoksik mitokondri ve sitozol arasındaki çalışması. (Gupta ve Igamberdiev, 2016’dan
değiştirilerek)

Çeşitli biyotik faktörlere bağlı olarak RNS oluşumu, dokuda oksidatif hasara neden olmakta (Kapoor vd., 2019) ve bazen bunların bozulmuş şekilde uzaklaştırılması bile bitkiler üzerinde olumsuz etkilere neden olabilmektedir. Mitokondri oksidatif enerji üretim bölgesidir. Aerobik hücrelerdeki çeşitli biyosentetik reaksiyon yollarından, herhangi bir mitokondriyal fonksiyon bozukluğu, hücre fonksiyonunda bozulmaya ve çeşitli anormalliklerin gelişmesine neden olmaktadır. Hücresel anormallikler ya da bozulmaların, yüksek seviyelerdeki reaktif oksijen türleriyle uyarıldığı bildirilmektedir (Adams vd., 2015; Kapoor vd., 2019). Foresi vd. (2010), Ostreoccus tauri'nin (deniz yeşili algi) bitkiler içerisinde NOS üreten tek tür olduğunu bildirmiştir. Bitkilerde, güçlü NO kaynağı olan enzimatik olmayan ve enzimatik sistemler bulunmaktadır (Malerba ve Cerena, 2015). Ayrıca, farklı bitki türlerinin ekstraktlarındaki 1arginin bağımlı NOS aktivitesi ile ilgili çeşitli veriler bildirilmiştir (Del Río, 2015). NOS aktivitesi, bitki dokularındaki peroksizom organelinde gözlenmiştir (Luis ve Río, 2013). Peroksizomlara ek olarak, NO üreten kloroplast (Jasid vd., 2006) ve mitokondri (Gupta ve Kaiser, 2010) gibi organellerde bildirilmiştir.

Ayrıca, nitrik oksit, bitkilerin büyümesi ve gelişimi için hücre içi ve hücreler arası sinyalde önemli bir rol oynamaktadır. Sekonder uyarıcıları harekete geçirerek çeşitli patolojik ve fizyolojik süreçlerde, biyotik ve abiyotik stres koşullarında, hücre duvarı lignifikasyonlarında, yaşlanma ve kök organogenezini içeren gen transkripsiyon mekanizmasında birçok görevi bulunmaktadır (Adams vd., 2015; Kapoor vd., 2019).

\section{Çeşitli Stres Koşullarında Bitkilerde RNS Üretimi, Taşınması ve Dağıtımı}

RNS üretiminde iki farklı yol tanımlanmaktadır. Oksidatif yol, nitrik oksit sentaz benzeri aktivite (NOS benzeri), poliaminler (PA) ve hidroksilamin bazlı üretimden oluşmaktadır. İndirgenmiş yol ise, nitrit-nitrik oksit redüktaz kompleksi ile nitrat redüktaz (NR), nitrik oksiti oluşturan nitrit redüktaz kompleksi ile NR, mitokondriyal ve plastid elektron taşıma zinciri, peroksizomal nitrik oksit sentaz benzeri aktivite ve snitrosoglutatyon redüktaz aktivitesini içermektedir. Yürütülen çalışmalar RNS ve türevlerinin apoplast, sitoplazma, plazma zarı ve kloroplast, mitokondri ve peroksizomlar gibi çeşitli hücre organellerinde üretildiğini ortaya koymaktadır. $\mathrm{ONOO}^{-}$, $\cdot \mathrm{NO}$ ve $\mathrm{O} 2 \cdot-$ özellikle süperoksitin üretildiği bölgelerde reaksiyon sonucu meydana gelmektedir. Nitritin enzimatik olmayan bir şekilde ·NO'ya indirgenmesi düşük pH'da gerçekleşmekte ya da yüksek indirgeyici koşullar ve yüksek nitrat seviyesi gerekmektedir. Bu durum arpa tohumunda aleuron tabakasının apoplastında gözlenmiştir. Poliaminler (PA) stres koşullarında antioksidan aktiviteye sahip küçük alifatik aminlerdir. Tuz stresi koşullarında PA, ROS ve NO arasında etkileşim olduğu belirtilmektedir. PA'lar, tuz stresi altında oksidatif ·NO sentez yoluna katılmakta fakat mekanizmaları bilinmemektedir. Putresin, spermidin ve spermin gibi PA'ların dışarıdan uygulanması, Arabidopsis fidelerinde NO üretimine neden olmaktadır. Tuzluluk stresi koşullarındaki PA'lar narenciye bitkilerinde oksidatif ve nitrosatif stresi artırabilmekte ve strese bağlı fenotipleri tersine çevirebilmektedir. Bitkilerde, sitoplazmik NR, çeşitli gelişim süreçleri, stoma hareketleri ve biyotik ve abiyotik stres koşullarında $\cdot$ NO sentezi için potansiyel bir enzimdir. Soğuk stresi ve ozmotik stres, -nitrit redüktaz aktivitesi ile birlikte NO üretimini tetiklemektedir (Saddhe vd., 2019). Nitröz oksit, bitki patojenlerine karşı bir savunma tepkisi olarak ROS ile koordineli olarak çalışmaktadır. Genel olarak, bitkiler ekolojik veya abiyotik stres koşullarında iken, RNS ve ROS'un aşırı miktarda üretilmesi söz konusudur (Kim vd. 2018; Türkan, 2018). Tekrarlayan NO ve ROS sentezi normalde büyüme ve gelişmenin farklı yönlerini düzenleyen ve ayrıca çevresel 
streslere ve patojen saldırılarına verilen tepkiler sırasında hasar görmüş veya enfekte olmuş hücreleri elimine eden önemli bir mekanizma olan programlanmış hücre ölümlerini engellemektedir (Wang vd., 2013; Kim vd., 2018).

$\mathrm{O}_{2}$ varlı̆̆ında NO'nun GS-O'yu oluşturan S-nitrosilasyon reaksiyonu sonucu GSH ile reaksiyona girdiği, özellikle de farklı bitki türlerinde görülen önemli bir NO biyoaktivite deposu olduğu belgelenmiştir. Oysa RNS peroksinitrit $\left(\mathrm{ONOO}^{-}\right)$, bir nitratlayıcı / oksidan $\mathrm{NO}$ ve $\mathrm{O}_{2}$ arasında güçlü reaksiyonla sentezlenen türler ve en sık peroksizomlar gibi organellerde bulunmaktadır. Bitki dokusunda NO ve GSNO varlığında, ONOO oluşumu, hem stres altında hem de protein nitrasyon ve S-nitrosilasyon gibi normal şartlarda bitkilerde PTM'lere (translasyon sonrası modifikasyon) yol açmaktadır. Peroksizomlarda, S-nitrosilasyon, gliko oksidaz, katalaz fonksiyonunu engellemekte ve hücresel seviyede $\mathrm{H}_{2} \mathrm{O}_{2}$ gibi sinyal molekülünü düzenleyebileceği öne sürülmektedir (OrtegaGalisteo vd., 2012). Oysa üretilen ONOO molekülü, tirozin nitrasyonunu sentezlemekte ve bitkilerde nitrosatif bir değişime neden olmaktadır. Ayrıca bazal endojen nitrasyonunun düzenleyici bir işlevi olabilir. Bezelye bitkilerinde EM-immünogold etiketleme üzerine yapılan son çalışmalar, kloroplast, sitozol, mitokondri ve peroksizomlara ilave olarak, yaprak hücrelerinin farklı bölümlerinde nitratlı proteinlerin varlı̆̆ını ortaya çıkarmıştır. Buna ek olarak, izole bezelye yapră̆ı peroksizomlarının proteomik olarak değerlendirilmesi, nitrasyon için hedef enzim olan peroksizomal NADH'ye bağlı hidroksipüvat redüktazın, peroksinit öncülüğünde reaksiyon ile ortaya çıktığını gösteriştir (Del Río, 2015; Türkan, 2018; Kapoor vd., 2019).

ROS ve RNS'nin hücreler arası ve hücre içi moleküler iletişimde kilit bir rolü olduğu kesin olarak belirlenmiş olmasına rağmen, ROS sinyalinin başlatılması, algılama ve tepki mekanizmaları ve üretim ile süpürme arasındaki hassas dengenin nasıl olduğu hakkındaki bilgiler kısıtlıdır. Ayrıca RNS, ROS, hücresel redoks değişiklikleri, kalsiyum sinyalleri, hormonlar (oksin, sitokinin, salisilik asit, jasmonik asit ve etilen) ve diğer haberci moleküllerin aracılık ettiği yollar arasındaki etkileşimler bulunmaktadır. Önemli fizyolojik etkileri anlamak için, farklı fizyolojik koşullar altında birçok yüksek bitki türünde tespit edilen l-arginin bağımlı nitrik oksit sentaz (NOS) aktivitesinden sorumlu proteinleri veya genleri tanımlamak oldukça önemlidir. NO ve GSNO'nun bitki dokularındaki varlığı sonucu ONOO'nun oluşumu, önemli kovalent postranslasyonal modifikasyonlar (PTM'ler), bitkilerde S-nitrosilasyonu ve proteinlerin nitratlanması kontrol ve stres koşullarında gerçekleşebilir. Peroksizomlarda, katalaz ve gliko oksidaz aktivitesi Snitrosilasyon ile inhibe edilir ve bu, $\mathrm{H}_{2} \mathrm{O}_{2}$ gibi kilit sinyal moleküllerinin hücresel seviyesini düzenleyebilir (Del Río, 2015).

\section{Nitrik oksit (NO)}

Nitrik oksitin (NO) 1987'de hayvanlarda önemli bir sinyal molekülü olduğu tartışılmış (Palmer vd., 1987), daha sonra bitkideki rolünün de bildirilmesiyle (Lazalt vd., 1997; Delledonne vd., 1998; Durner vd., 1998) bitkilerdeki işlevinin araştırılması konusunda kapsamlı çalışmalar yapılmıştır. NO, süperoksit anyon $\left(\mathrm{O}_{2}{ }^{-}\right)$ve hidrojen peroksit $\left(\mathrm{H}_{2} \mathrm{O}_{2}\right)$ gibi reaktif oksijen türleri (ROS) ve hidrojen sülfit $\left(\mathrm{H}_{2} \mathrm{~S}\right)$ ile birlikte, hücrelerin aktivitesini ve proteinlerin işlevini kontrol etmeye yardımcı olan hücrelerde nispeten reaktif küçük moleküller grubunun bir parçası olarak çalışmaktadır (Şekil 3). NO tohum çimlenmesi, kök gelişimi, stoma kapanması, patojenlerle mücadele, bitki üremesi ve stres tepkilerinde rol oynamaktadır. (Adams vd., 2015; Procházková vd., 2015; Hancock ve Neill, 2019). Bitkilerde NO metabolizması ile ilgili tartışmalardan birisi de enzimatik kaynakların belirlenmesidir. Nitrat redüktazın (NR) dahil olduğu konusunda çok az şüphe olsa da, nitrik oksit sentaz (NOS) benzeri enzimin tanımlanması oldukça zor olmakta ve böyle bir proteinin alglerde bulunduğu, yüksek bitkilerde bulunmadığı açıkça ortaya çıkmaktadır. NO ile yapılan doğrudan reaksiyonların, peroksinitrit ve nitrosotioller gibi yeni sinyal molekülleri üretmesi ve sinyal tepkilerinin olası sonucunu belirleyecek kimyasal rekabetlerin olması da muhtemeldir. Bitki hücrelerinde NO'ların nasıl üretildiği ve bu kompleks ortama NO'nun nasıl uyduğunun anlaşılması gerekmektedir (Hancock ve Neill, 2019). 


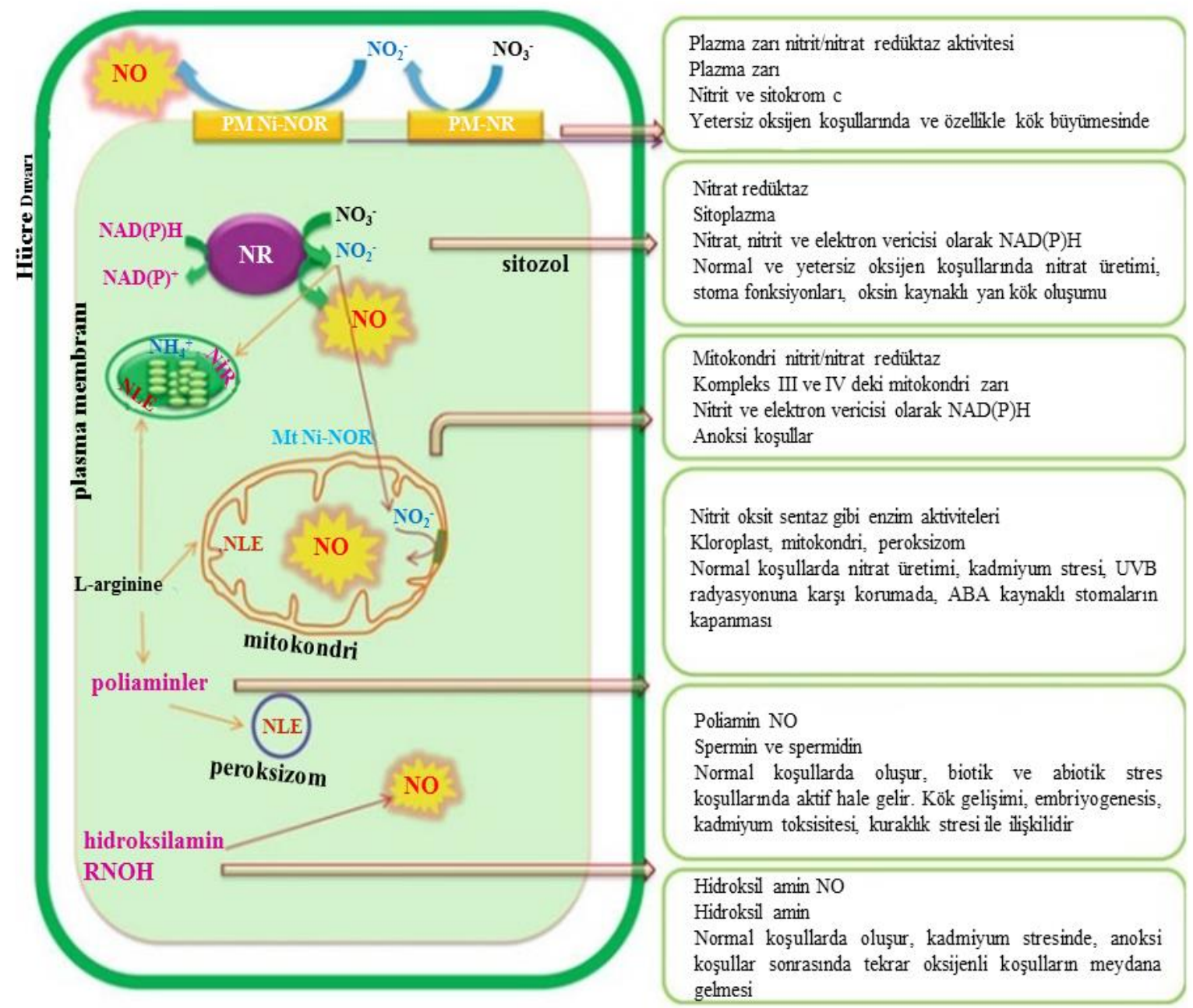

Şekil 3. Bitki hücresinin çeşitli klsımlarında NO üretimi (Gupta ve Igamberdiev, 2015'den değisştirilerek)

\section{Bitki Hücrelerinde Nitrik Oksit Üretimi}

Bitki hücrelerinin NO ürettiği ve buna tepki verebildiği gözlenmektedir. Bu nedenle, NO birikimine yönelik bazıları enzime bağımlı ve bazıları enzimden bağımsız olan birden fazla yol önerilmiştir. Temel NO kaynaklarından birisi, nitrat redüktaz (NR) enzimidir. Stomaların kapanmasında önemli olduğu bildirilmiştir (Desikan vd., 2002). Diğer molibden bazlı enzimler de önemli olabilirken (Rockel vd., 2002), hipoksik koşullar altında da olsa, NO üretebilen başka bir enzim, ksantin oksidoredüktazdır (XOR) (Millar vd., 1998). Bununla birlikte, en dikkat çeken enzim nitrik oksit sentazdır (NOS). NOS'un yüksek bitkilerden izole edildiğine dair çalışmalar olmasına rağmen, doğrudan NO üreten proteinlerin tanımlanmadığı ortaya konmuştur (Hancock ve Neill, 2019).

Bazı ilkel bitki gruplarında NOS homologları tanımlanmıştır (Astier vd., 2018). İki yeşil alg genomu, Ostreococcus tauri ve Ostreococcus lucimarinus için NOS, sekans kanıtı göstermiştir (Foresi vd., 2010). Kara bitkilerinden elde edilen 1087 dizili transkriptom incelendiğinde tipik bir NOS dizisi bulunmamıştır. Aksine, analiz edilen 265 alg türünden 15'i NOS sekanslarına ilişkin kanıtlar göstermiştir. Araştırıcılar bitkilerin hayvanlarda bulunanlardan farklı bir mekanizma kullanarak NO üretmeleri gerektiği sonucuna varmışlardır (Jeandroz vd., 2016). Bitkiler benzer olan redüktazlara sahiptir. Arabidopsis, p450 redüktaz olarak tanımlanabilen iki proteine sahiptir: NP_001190823 ve NP_194750. eNOS 952-980 gibi kısa sekansların bazıları, aranan bitki genomlarında redüktans kanıtı olarak bulunmuştur. Bu nedenle, bitkilerde NOS benzeri herhangi bir enzimin özel bir redüktaza sahip olmaması mümkündür, fakat büyük olasılıkla çok işlevli olan diğer redüktazlardan elektronları çekmesi de mümkündür. NOS'un diğer peptidlerle etkileşime girmesi olasıdır ve bu da önemli fonksiyonel bölgeleri tanımlamanın bir yolu olabilir. Hem Arabidopsis hem de çeltik proteinlerinde homo sapiens NOS ile etkileşime giren protein izoformunun (NP_057037) ortaya çıkarılması önemli olup, bunlar NOS ile etkileşime giren proteinler olarak açıklanmıştır (sırasıyla XP_020890108.1 ve XP_006649867.1) (Hancock ve Neill, 2019).

\section{NO ve Diğer Reaktif Sinyal İlişkisi}

Nitrik oksitin kimyası incelendiğinde radikal bir form içerdiği varsayılmaktadır. Bununla birlikte, bir elektronun kaybı veya kazanılmasıyla birlikte, diğer formlar nitroksil $\left(\mathrm{NO}^{-}\right)$ve nitroonyum $\left(\mathrm{NO}^{+}\right)$iyonları meydana gelmektedir. Bitkilerde kadmiyum stresi 
koşullarında sitoplazma gibi hücresel bölgelerde $\mathrm{NO}$ ve ROS birikimi ve $\mathrm{H}_{2} \mathrm{~S}$ oluşumu gözlenmektedir. Bu nedenle, NO'nun mevcut diğer bileşiklerle etkileşiminin nasıl olduğu oldukça önemlidir (Zheng vd., 2009; Hancock ve Neil, 2019).

$\mathrm{NO}$ ve ROS'un en iyi bilinen reaksiyonu, peroksitit $\left(\mathrm{ONOO}^{-}\right)$üreten $\mathrm{NO}$ ile süperoksit anyonunun arasındadır (Şekil 4). Bunun potansiyel olarak önemli iki sonucu vardır. İlk olarak, reaksiyon hem $\mathrm{O}_{2}$ hem de NO'yu hücreden uzaklaştırmakta ya da hücrenin çevresi, her ikisinin de biyo-kullanılabilirliğini azaltmaktadır. Böylece ROS'a bağll sinyalizasyon, belki de $\mathrm{H}_{2} \mathrm{O}_{2}$ ve $\mathrm{NO}$ sinyalleşmesini azaltabilmektedir. İkincisi, kendisi bir sinyal molekülü olarak hareket eden belki de ROS veya NO sinyallerinden kaynaklanabilecek olan yeni bir bileşik üreterek farklı bir cevap vermektir (Hancock ve Neil, 2019).

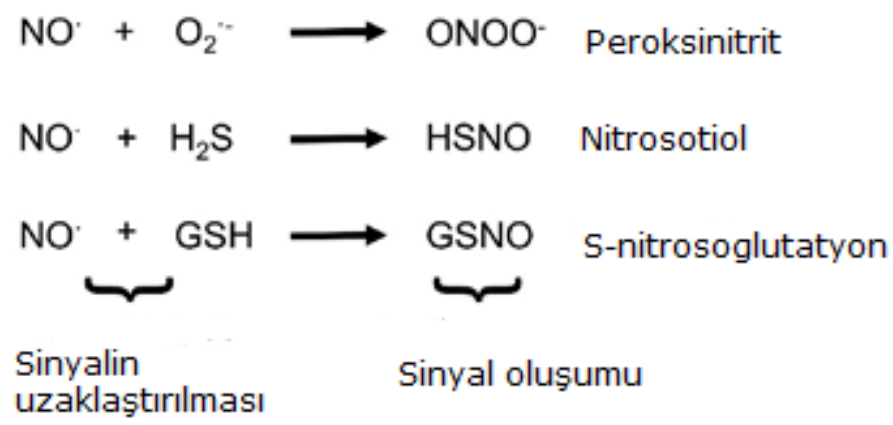

Şekil 4. NO ile bazı reaksiyonlar (Hancock ve Neill, 2019'dan değiştirilerek)

NO üretimi antioksidanlar bakımından zengin bir ortam oluşturacaktır. NO, enzimatik antioksidanların aktivitesini etkilemekte, peroksinitrit aracılığı ile SOD aktivitesini değiş̧tirmektedir ve böylece hücrenin süperoksit anyonlarını ve $\mathrm{H}_{2} \mathrm{O}_{2}$ üretme kapasitesini düşürmektedir. Benzer şekilde, NO katalaz aktivitesini de değiştirebilir, böylece hücrenin $\mathrm{H}_{2} \mathrm{O}_{2}$ 'yi kaldırma kapasitesini azaltabilir, ROS aracılı sinyalleşmeyi uzatabilir. Hücrenin antioksidan kapasitesinin büyük bir kısmı, düşük molekül ağırlıklı antioksidanların varlığından kaynaklanmaktadır. Hücrelerde bir dizi düşük moleküler ağırlıklı tiyol bulunmaktadır, bunlardan en önemlilerinden birisi de glutatyondur. NO, bir redoks bileşiği olduğu gibi, hücre içi redoks durumunun değişmesine de yol açması mümkündür. Hücre içi redoks ortamının statik olmadığı ve hücrelerin apoptotik bir durumda olması durumunda daha fazla oksitleyici olduğu bilinmektedir, ancak redoks ortamının, herhangi bir NO çiftinin durumunu ve dolayısıyla herhangi bir NO türünün ömrünü belirlemesi de mümkündür. NO ve glutatyon GSNO üretmek için birlikte reaksiyona girebilmekte ve bu durum potansiyel olarak hücrelerdeki GSH / GSSG seviyelerini azaltmaktadır (Kim vd., 2018; Hancock ve Neil, 2019).

GSNO bir donör ve dolayısıyla bir NO rezervuarı olarak işlev görebilir ve GSNO' nun NO ile karşılaştırıldığında belirgin ve örtüşen moleküler hedeflere sahip bazı NO etkilerine aracılık edebileceği de öne sürülmektedir. NO sinyaline müdahale edebilecek başka bir reaktif sinyal, hidrojen sülfittir $\left(\mathrm{H}_{2} \mathrm{~S}\right)$. $\mathrm{H}_{2} \mathrm{~S}$ 'in son zamanlarda hem hayvanlarda hem de bitkilerde önemli bir sinyal molekülü olduğu bulunmuştur (Hancock ve Neil, 2019).

$\mathrm{H}_{2} \mathrm{~S}$, nitrosotiol üretmek için doğrudan $\mathrm{NO}$ ile reaksiyona girebilir (Şekil 4). $\mathrm{H}_{2} \mathrm{~S}$ ayrıca hücrelerdeki GSH seviyelerini de yükseltebilir ve bu nedenle GSNO birikimini değiştirme potansiyeline sahip olabilir. Son zamanlarda hayvanlarda ve bitkilerde sinyalleşmenin hidrojen gazı $\left(\mathrm{H}_{2}\right)$ içerebileceği öne sürülmüş̧ür (Wilson vd., 2017). $\mathrm{H}_{2}$ 'nin varlı̆̆ hücrelerde antioksidan seviyelerini değiştirebilir (Ohta, 2015) ve dolaylı olarak NO metabolizmasını da değiştirebilir. $\mathrm{H}_{2}$ gazının bazı etkileri için NO'ya ihtiyaç duyulduğu bildirilmiştir (Zhu vd., 2016a, Zhu vd., 2016b) ve gelecekte $\mathrm{NO}$ ve $\mathrm{H}_{2}$ sinyalleri arasında daha fazla etkileşimin olacağı vurgulanmıştır (Hancock ve Neil, 2019).

\section{NO’nun Bitki Fizyolojisindeki Rolü}

NO bitki-patojen ilişkisinde bitki savunma mekanizması yönünden önemli bir moleküldür. Bu önemli etkisinin yanı sıra tohum ve polen çimlenmesi, bitki büyüme ve gelişmesi, primer kök büyümesi, hücre uzamasının düzenlenmesi, bitki olgunlaşması ve yaşlanması, stoma hareketleri, yer çekimine yönelim, mitokondrinin çalışması ve fotosentez gibi çok sayıda olayda rol oynamaktadır. Benzer şekilde kuraklık, tuzluluk ve yüksek sıcaklık stresi gibi abiyotik strese toleranslılıkta; hastalıklara dayanıklılık gibi biyotik streste; programlı hücre ölümü gibi fizyolojik olaylarda ve baklagillerde biyolojik azot özümlemesinde görev almaktadır. Moleküler organizasyonda hastalıklara dayanıklılık süreçlerinin transkripsiyon düzeyinde düzenlenmesinde, strese bağlı transkripsiyon faktörlerinin ekspresyonu ve sinyal molekülü olarak kinazlar, salisilik asit ve jasmonik asit gibi diğer sinyal molekülleri ile etkileşime girerek gen ekspresyonu düzenlemektedir (Procházková vd., 2015).

Son zamanlarda, NO'nun hücre içi rolü üzerinde de durulmaktadır. NO'nun reaktif oksijen türlerinin (ROS), net NO üretiminin ve primer metabolizmanın akonitazın inhibisyonu yoluyla amino asit biyosentezine kaymasına neden olacak şekilde üretilmesi, net NO üretimi ve mitokondriyal alternatif oksidaz aktivitesini modüle ettiği vurgulanmıştır. Peroksizomlarda, katalaz, glikoksilat oksidaz ve malat dehidrogenaz gibi NO nitrosilat proteinleri fotorespirasyon, $\beta$-oksidasyon ve ROS detoksifikasyonunda rol oynadığı gözlenmiştir (Procházková vd., 2015). 
Çalışmalar hemen hemen bütün türlerin mitokondrilerinin nitriti, nitrik okside (NO) indirgediğini göstermektedir (Şekil 2). Örneğin siliat protistlerinden ve Fusarium mantarından izole edilen mitokondri, nitriti NO'ya indirgeme kapasitesine sahiptir (Tielens vd., 2002). Bitkilerde buna ilk örnek yeşil alg Chlorella sorokiniana'da nitrit ilavesi ile NO oluşumunun gözlenmesi ve mitokondrial elektron taşıma zincirinin inhibitörleri tarafından bloke edilebilmesiydi (Tischner vd., 2004). Daha sonra, tütünde, nitritin NO'ya indirgendiği ve mitokondriyal inhibitör uygulamasının bu reaksiyonu bastırdığı gözlenmiştir (Planchet vd., 2005). Daha sonra Gupta vd. (2005) NO'ya olan nitrit indirgenmesinin, bezelye, arpa, Arabidopsis ve tütün gibi çeşitli bitkilerin kök mitokondrilerinde meydana geldiğini ve nitritin NO'ya indirgenmesi için Km değerini belirlediklerini vurgulamışlardır. Bu NO üretimi için gerekli olan nitrit konsantrasyonunun tahmin edilmesine olanak sağlamıştır. Soya fasulyesi (Glycine max)'ın fotosentez inhibe edici bir herbisitle veya karanlıkta inkübasyonla muamelesi nitrit birikimine ve daha sonra bilinmeyen bir mekanizma ile nitritten elde edilen $\mathrm{NO}_{2}$ emisyonuna yol açmaktadır (Mayer vd., 2018). Hipoksi koşullar altında, amonyum nitrit indirgenmesini engellediğinden (Botrel vd., 1996), biriken nitrit NO oluşumu için bir substrat olarak işlev görmektedir. Gupta ve Kaiser (2010) bu sürecin zarda meydana geldiğini ancak mitokondri matrisinde olmadığını ifade etmişlerdir. Mitokondriyal elektron taşıma zincirinin III ve IV komplekslerinin NO üretim bölgeleri olduğu gösterilmiştir. Kompleks III, bu bölgedeki oksijenin bir elektron indirgenmesiyle üretildiği gibi, süperoksitin benzer bir şekilde bir elektron sızıntısı yoluyla NO üretebileceğini göstermektedir. COX ile NO'dan nitrit indirgenme mekanizmaları hala araştırılmaktadır ve bu mekanizmanın açıklaması için çeşitli modeller mevcuttur. Oksijen, nitrit ve NO mevcudiyeti, sırasıyla sitokrom c'nin redoks durumuna bağlı olan a3 ve bakır B (Fea3CuB) içeren COX redoks durumunu belirlemektedir. Oksijen olmadığında, $\mathrm{Fe}^{+2}$ nitritin $\mathrm{NO}^{\prime}$ ya indirgenmesi için elektronu vermektedir. Mitokondride $\mathrm{NO}^{\prime} y u$ indirgeyen diğer nitrit bölgeleri sitokrom c'nin kendisini ve diğer hemeproteinleri içermektedir (Basu vd., 2008).

Bununla birlikte, yonca (Medicago truncatula) nodüllerinde NO üretimi, alternatif oksidaz (AOX) inhibitörü propilgallata karş1 tamamen duyarsızdır (Horchani vd., 2011). Çeşitli çalışmalarda bildirilen AOX inhibitörlerinin etkisi, peroksidazlar ve diğer hemeproteinler dahil diğer proteinler üzerindeki etkileriyle açılanabilmiş̧ir. Anoksi (oksijensiz) koşullar altında mitokondri önemli miktarda NO üretmektedir (Gupta vd., 2005). Üretilen NO'nun, nitrozatif stresi önlemek için çok hızlı bir şekilde geri dönüştürülmesi gerekmektedir. NO'nun etkisiz hale getirilmesi (süpürülmesi), fitoglobin demir iyonunun oksidasyonunu, metaloglobin ve nitratın oluşmasını içermektedir. Fitoglobin-NO döngüsünün çalışması nitrat ve nitritin geri dönüşümü için ve NADH ve NADPH fazlalığının oksidasyonu için gereklidir

Nitrit indirgenmesi ve NO oluşumu COX ve kompleks III'te (bc1) meydana gelmektedir. NO, oksijenli simbiyotik olmayan fitoglobin $\left(\mathrm{PgbO}_{2}\right)$ tarafından nitrat $\left(\mathrm{NO}^{-3}\right)^{\prime}$ 'e dönüştürüldüğü sitozole geçmektedir. Bu reaksiyonda oluşan Metphytoglobin (MetPgb), metphytoglobin redüktaz (MetPgbR) ile geri dönüştürülmekte ve nitrat, nitrat redüktaz (NR) ile indirgenip, nitrat, mitokondriye nitrit taşıyıcı (NT) ile taşınmaktadır. NAD(P)H, mitokondriyal dehidrogenazlar (ND) ile oksitlenmektedir. (Q, ubiquinon; c, sitokrom c.) (Gupta ve Igamberdiev, 2016)

\section{Sonuç}

Abiyotik ve biyotik stres koşullarında olduğu kadar, normal yetiştirme şartlarında bitki büyüme ve gelişiminde çeşitli biyolojik süreçlerin düzenlenmesinde reaktif azot türleri (RNS) rol oynamaktadır. RNS, nitrik asit $(\mathrm{NO})$ ve nitrik dioksit $\left(\mathrm{NO}_{2}\right)$ gibi radikalleri ve ayrıca nitröz asit $\left(\mathrm{HNO}_{2}\right)$ ve dinitrojen tetroksit $\left(\mathrm{N}_{2} \mathrm{O}_{4}\right)$ gibi radikal olmayanları içermektedir. Mitokontrideki NO üretiminin elektron taşıma zinciri, kompleks I, II, III ve IV, alternatif NAD(P)H dehidrogenazlar, alternatif oksidaz ve sitokrom c gibi yolakların tümünde ortaya çıkabileceği bildirilmiştir. NO, enzimatik antioksidanların aktivitesini olumsuz yönde etkilemekte ve SOD aktivitesini değiştirmektedir. Böylece hücrenin süperoksit anyonlarını ve $\mathrm{H}_{2} \mathrm{O}_{2}$ üretme kapasitesini düşürmektedir. Bitkilerde, sitoplazmik NR (nitrat redüktaz), çeşitli gelişim süreçleri, stoma hareketleri ve biyotik ve abiyotik stres koşullarında NO sentezi için potansiyel bir enzimdir.

\section{Kaynakça}

Adams, L., Franco, M. C., \& Estevez, A. G. (2015). Reactive nitrogen species in cellular signaling. Experimental Biology and Medicine, 240(6), 711-717.

Astier, J., Jeandroz, S., \& Wendehenne, D. (2018). Nitric oxide synthase in plants: The surprise from algae. Plant science: An International Journal of Experimental Plant Biology, 268, 64.

Basu, S., Azarova, N. A., Font, M. D., King, S. B., Hogg, N., Gladwin, M. T., \& Kim-Shapiro, D. B. (2008). Nitrite reductase activity of cytochrome c. Journal of Biological Chemistry, 283(47), 32590-32597.

Beligni, M. V., Fath, A., Bethke, P. C., Lamattina, L., \& Jones, R. L. (2002). Nitric oxide acts as an antioxidant and delays programmed cell death in barley aleurone layers. Plant physiology, 129(4), 1642-1650.

Botrel, A., Magné, C., \& Kaiser, W. M. (1996). Nitrate reduction, nitrite reduction and ammonium assimilation in barley roots in response to anoxia. Plant Physiology and Biochemistry, 34(5), 645-652.

De Michele, R., Vurro, E., Rigo, C., Costa, A., Elviri, L., Di Valentin, M., \& Schiavo, F. L. (2009). Nitric oxide is involved in cadmium-induced programmed cell death in Arabidopsis suspension cultures. Plant Physiology, 150(1), 217-228.

Del Río, L. A. (2015). ROS and RNS in plant physiology: an overview. Journal of Experimental Botany, 66(10), 2827-2837.

Delledonne, M., Xia, Y., Dixon, R. A., \& Lamb, C. (1998). Nitric oxide functions as a signal in plant disease resistance. Nature, 394(6693), 585-588.

Desikan, R., Griffiths, R., Hancock, J., \& Neill, S. (2002). A new role for an old enzyme: nitrate reductase-mediated nitric oxide generation is required for abscisic acid-induced stomatal closure in Arabidopsis thaliana. Proceedings of the National Academy of Sciences, 99(25), 16314-16318. 
Durner, J., Wendehenne, D., \& Klessig, D. F. (1998). Defense gene induction in tobacco by nitric oxide, cyclic GMP, and cyclic ADPribose. Proceedings of the National Academy of Sciences, 95(17), 10328-10333.

Fewson, C. A., \& Nicholas, D. J. D. (1960). Utilization of nitric oxide by micro-organisms and higher plants. Nature, 188, 794-6.

Foresi, N., Correa-Aragunde, N., Parisi, G., Caló, G., Salerno, G., \& Lamattina, L. (2010). Characterization of a nitric oxide synthase from the plant kingdom: NO generation from the green alga Ostreococcus tauri is light irradiance and growth phase dependent. The Plant Cell, 22(11), 3816-3830.

Gupta, K. J., \& Rolletschek, H. (2013). Plant respiratory metabolism: a special focus on the physiology of beetroot (Beta vulgaris L.) mitochondria. In Red Beet Biotechnology (pp. 91-104). Springer, Boston, MA.

Gupta, K. J., \& Igamberdiev, A. U. (2015). Compartmentalization of reactive oxygen species and nitric oxide production in plant cells: an overview. In Reactive Oxygen and Nitrogen Species Signaling and Communication in Plants (pp. 1-14). Springer, Cham.

Gupta, K. J., Stoimenova, M., \& Kaiser, W. M. (2005). In higher plants, only root mitochondria, but not leaf mitochondria reduce nitrite to NO, in vitro and in situ. Journal of Experimental Botany, 56(420), 2601-2609.

Gupta, K. J., \& Kaiser, W. M. (2010). Production and scavenging of nitric oxide by barley root mitochondria. Plant and Cell Physiology, 51(4), 576-584.

Gupta, K. J., \& Igamberdiev, A. U. (2016). Reactive nitrogen species in mitochondria and their implications in plant energy status and hypoxic stress tolerance. Frontiers in Plant Science, 7, 369.

Gupta, K. J., Kumari, A., Florez-Sarasa, I., Fernie, A. R., \& Igamberdiev, A. U. (2018). Interaction of nitric oxide with the components of the plant mitochondrial electron transport chain. Journal of Experimental Botany, 69(14), 3413-3424.

Hancock, J. T., \& Neill, S. J. (2019). Nitric Oxide: Its generation and interactions with other reactive signaling compounds. Plants, 8(2), 41.

Hebelstrup, K. H., \& Møller, I. M. (2015). Mitochondrial signaling in plants under hypoxia: use of reactive oxygen species (ROS) and reactive nitrogen species (RNS). In Reactive Oxygen and Nitrogen Species Signaling and Communication in Plants (pp. 63-77). Springer, Cham.

Horchani, F., Prévot, M., Boscari, A., Evangelisti, E., Meilhoc, E., Bruand, C., \& Brouquisse, R. (2011). Both plant and bacterial nitrate reductases contribute to nitric oxide production in Medicago truncatula nitrogen-fixing nodules. Plant Physiology, 155(2), 1023-1036.

Jasid, S., Simontacchi, M., Bartoli, C. G., \& Puntarulo, S. (2006). Chloroplasts as a nitric oxide cellular source. Effect of reactive nitrogen species on chloroplastic lipids and proteins. Plant Physiology, 142(3), 1246-1255.

Jeandroz, S., Wipf, D., Stuehr, D. J., Lamattina, L., Melkonian, M., Tian, Z., \& Wendehenne, D. (2016). Occurrence, structure, and evolution of nitric oxide synthase-like proteins in the plant kingdom. Science Signaling, 9(417), re2-re2.

Kapoor, D., Singh, S., Kumar, V., Romero, R., Prasad, R., \& Singh, J. (2019). Antioxidant enzymes regulation in plants in reference to reactive oxygen species (ROS) and reactive nitrogen species (RNS). Plant Gene, 19, 100182.

Kim, Y., Mun, B. G., Khan, A. L., Waqas, M., Kim, H. H., Shahzad, R., \& Lee, I. J. (2018). Regulation of reactive oxygen and nitrogen species by salicylic acid in rice plants under salinity stress conditions. Plos One, 13(3).

Lazalt, A. M., Beligni, M. V., \& Lamattina, L. (1997). Nitric oxide preserves the level of chlorophyll in potato leaves infected by Phytophthora infestans. European Journal of Plant Pathology, 103(7), 643-651.

Leshem, Y. Y., \& Haramaty, E. (1996). Plant aging: the emission of NO and ethylene and effect of NO-releasing compounds on growth of pea (Pisum sativum) foliage. Journal of Plant Physiology, 148(3-4), 258-263.

Lindermayr, C., \& Durner, J. (2009). S-Nitrosylation in plants: pattern and function. Journal of Proteomics, 73(1), 1-9.

Luis, A., \& Río, D. (Eds.). (2013). Peroxisomes and their key role in cellular signaling and metabolism. Springer Netherlands.

Malerba, M., \& Cerana, R. (2015). Reactive oxygen and nitrogen species in defense/stress responses activated by chitosan in sycamore cultured cells. International Journal of Molecular Sciences, 16(2), 3019-3034.

Mayer, D., Mithöfer, A., Glawischnig, E., Georgii, E., Ghirardo, A., Kanawati, B., \& Gaupels, F. (2018). Short-term exposure to nitrogen dioxide provides basal pathogen resistance. Plant Physiology, 178(1), 468-487.

Millar, T. M., Stevens, C. R., Benjamin, N., Eisenthal, R., Harrison, R., \& Blake, D. R. (1998). Xanthine oxidoreductase catalyses the reduction of nitrates and nitrite to nitric oxide under hypoxic conditions. FEBS letters, 427(2), 225-228.

Noritake, T., Kawakita, K., \& Doke, N. (1996). Nitric oxide induces phytoalexin accumulation in potato tuber tissues. Plant and Cell Physiology, 37(1), 113-116.

Ohta, S. (2015). Molecular hydrogen as a novel antioxidant: overview of the advantages of hydrogen for medical applications. In Methods in Enzymology (Vol. 555, pp. 289-317). Academic Press.

Ortega-Galisteo, A. P., Rodríguez-Serrano, M., Pazmiño, D. M., Gupta, D. K., Sandalio, L. M., \& Romero-Puertas, M. C. (2012). SNitrosylated proteins in pea (Pisum sativum L.) leaf peroxisomes: changes under abiotic stress. Journal of Experimental Botany, 63(5), 2089-2103.

Palmer, R. M., Ferrige, A. G., \& Moncada, S. (1987). Nitric oxide release accounts for the biological activity of endothelium-derived relaxing factor. Nature, 327(6122), 524-526.

Planchet, E., Jagadis Gupta, K., Sonoda, M., \& Kaiser, W. M. (2005). Nitric oxide emission from tobacco leaves and cell suspensions: rate limiting factors and evidence for the involvement of mitochondrial electron transport. The Plant Journal, 41(5), $732-743$.

Procházková, D., Wilhelmová, N., \& Pavlík, M. (2015). Reactive nitrogen species and nitric oxide. In Nitric Oxide Action in Abiotic Stress Responses in Plants (pp. 3-19). Springer, Cham.

Rockel, P., Strube, F., Rockel, A., Wildt, J., \& Kaiser, W. M. (2002). Regulation of nitric oxide (NO) production by plant nitrate reductase in vivo and in vitro. Journal of Experimental Botany, 53(366), 103-110.

Saddhe, A. A., Malvankar, M. R., Karle, S. B., \& Kumar, K. (2019). Reactive nitrogen species: paradigms of cellular signaling and regulation of salt stress in plants. Environmental and Experimental Botany, 161, 86-97. 
Schertl, P., \& Braun, H. P. (2014). Respiratory electron transfer pathways in plant mitochondria. Frontiers in Plant Science, $5,163$.

Tielens, A. G., Rotte, C., van Hellemond, J. J., \& Martin, W. (2002). Mitochondria as we don't know them. Trends in Biochemical Sciences, 27(11), 564-572.

Tischner, R., Planchet, E., \& Kaiser, W. M. (2004). Mitochondrial electron transport as a source for nitric oxide in the unicellular green alga Chlorella sorokiniana. FEBS letters, 576(1-2), 151-155.

Turkan, I. (2018). ROS and RNS: key signalling molecules in plants. Journal of Experimental Botany, 69(14), 3313-3315.

Wang, Y., Loake, G. J., \& Chu, C. (2013). Cross-talk of nitric oxide and reactive oxygen species in plant programed cell death. Frontiers in Plant Science, 4, 314.

Wilson, H. R., Veal, D., Whiteman, M., \& Hancock, J. T. (2017). Hydrogen gas and its role in cell signalling. CAB Rev., 12: 1-3.

Zheng, C., Jiang, D., Liu, F., Dai, T., Liu, W., Jing, Q., \& Cao, W. (2009). Exogenous nitric oxide improves seed germination in wheat against mitochondrial oxidative damage induced by high salinity. Environmental and Experimental Botany, 67(1), $222-227$.

Zhu, Y., Liao, W., Wang, M., Niu, L., Xu, Q., \& Jin, X. (2016). Nitric oxide is required for hydrogen gas-induced adventitious root formation in cucumber. Journal of Plant Physiology, 195, 50-58.

Zhu, Y., Liao, W., Niu, L., Wang, M., \& Ma, Z. (2016). Nitric oxide is involved in hydrogen gas-induced cell cycle activation during adventitious root formation in cucumber. BMC Plant Biology, 16(1), 146. 